\title{
NOMOKRASI ISLAM UNTUK INDONESIA
}

\author{
Al Chaidar \\ Program Studi Antropologi, Fakultas Ilmu Sosial dan Ilmu Politik \\ Universitas Malikussaleh \\ Korespondensi: alchaidar@unimal.ac.id
}

\begin{abstract}
Abstrak: Negara dalam Islam yang paling tepat adalah nomokrasi Islam, artinya kekuasaan yang didasarkan kepada hukum-hukum yang berasal dari Allah, "karena tuhan itu abstrak, maka hanya hukum Tuhan yang nyata". Nomokrasi Islam adalah suatu sistem pemerintahan yang didasarkan pada asas-asas dan kaidah-kaidah hukum Islam (Syari'ah) yang merupakan "Islamic rule of law". Untuk mewujudkan pemerintahan yang berdaya guna berhasil, bersih, amanah dan bertanggungjawab secara nomokratis, di Indonesia telah dimulai oleh Pemerintah Aceh yang telah berkomitmen untuk memperbaiki tatakelola Pemerintahan Indonesia dengan melakukan kebijakan reformasi birokrasi dan menetapkannya menjadi salah satu prioritas Pembangunan Aceh. Berkaitan dengan pelaksanaan penataan kelembagaan perangkat Indonesia telah di inisiasi di Aceh sejak tahun 2005 hingga akhir 2006. Dengan ditetapkannya UUPA maka terlihatlah gambaran baru dalam sistem penyelenggaraan pemerintahan daerah dan dalam rangka pelaksanaan otonomi khusus bagi Pemerintah Aceh. Sejalan dengan hal tersebut, Pemerintah menetapkan PP 41 Tahun 2007 tentang Organisasi Perangkat daerah sebagai suatu pedoman dalam penataan kelembagaan perangkat daerah di Indonesia. Semestinya Indonesia menerapkan sistem nomokrasi Islam sedari awal negara ini berdiri untuk menjaga sistem pemerintahan yang adil, efektif, efisien dan bertanggungjawab bagi seluruh rakyat.
\end{abstract}

Kata Kunci: nomokrasi, rule of law, teleokrasi, Aceh, Indonesia 


\section{A. Pendahuluan}

Negara yang menjadikan Syari'ah (hukum Islam) sebagai fondasinya, dalam konsepsi Malcolm H. Kerr (1966: 29) disebut dengan istilah nomokrasi Islam (Al Chaidar, 2013). Karakteristik Siyasah diniyah menurut Ibnu Khaldun ialah kecuali al-Qur'an dan Sunnah, akal manusia pun sama-sama berperan dan berfungsi dalam kehidupan negara. Waqar Ahmad Husaini mencatat bahwa nomokrasi Islam bertujuan untuk mewujudkan kesejahteraan masyarakat universal, baik di dunia maupun di akhirat (al-masalih al-kaffah). Waqar Husaini (1983: 217) menggunakan istilah "Negara Syari'ah" untuk siyasah diniyah atau nomokrasi Islam. Negara menurut Islam sangat berbeda dengan negara dalam perspektif Barat. Nomokrasi Islam atau negara Syari'ah (siyasah diniyah) atau Islamic rule of law bukanlah negara sekuler yang memisahkan antara agama dengan negara, begitu juga antara agama dengan hukum seperti pemahaman tentang negara yang berkembang di barat masa kini. Konsep Negara Hukum menurut Professor Muhammad Tahir Azhary (1991), dalam bukunya tentang negara hukum (dilihat dari segi hukum Islam, implementasinya pada periode Negara Madinah dan masa kini).

Menurut Ibnu Khaldun (1977), tipe Negara paling baik dan ideal di antara siyasah diniyah, siyasah 'aqliyah dan siyasah madaniyah adalah siyasah diniyah atau nomokrasi islam (Islamic nomocracy). Siyasah 'aqliyah hanya mendasarkan pada hukum sebagai hasil rasio manusia tanpa mengindahkan hokum yang bersumber dari wahyu. Siyasah madaniyah (Republik ala Plato) merupakan suatu Negara yang diperintah oleh segelintir golongan elit atas sebagian besar golongan budak yang tidak mempunyai hak pilih. Siyasah diniyah, kecuali syari'ah (hukum islam) orang menggunakan pula hukum yang bersumber dari akal manusia. Maka dari ketiga tipe Negara yang termasuk dalam bentuk mulk siyasi itu, maka secara teoretis menurut Ibnu Khaldun nomokrasi islam atau dalam istilahnya siyasah diniyah 'satu-satunya bentuk tata politik dan cultural yang permanen'.

Bukan hanya Ibnu Khaldun yang menyatakan bahwa konsep nomokrasi adalah konsep paling ideal untuk sebuah negara, tapi juga Tahir Azhari, salah satu teori beliau adalah traditional authority, kekuasaan yang didapat secara tradisional. Sejatinya nomokrasi sebagai solusi dalam mewujudkan kesejahteraan. 
rakyat semakin ambigu terhadap negara hingga melahirkan ketimpangan, kemiskinan, bahkan ketidakadilan. Negara yang dijalankan dengan sistem nomokrasi, jelas akan dapat mengatasi ketimpangan, kemiskinan bahkan ketidakadilan, dikarenakan semua dasar landasan hukum yang berlaku dalam dalam Negara tersebut berasal dari hukum Islam. Penghapusan pajak, penerapan zakat sebagai model negara dengan sistem nomokrasi, pemerintahan hadir untuk melayani dan mengayomi (layarberita.com, 02 Desember 2018).

Konsep syiasah diniyah atau nomokrasi Islam dewasa ini sangat layak diterapkan di Aceh, bahkan di Indonesia dalam hal ini jelas tidak bertentangan dengan konstitusi. Bahkan konstitusi memberi ruang untuk hal tersebut, berdasarkan Undang-undang Dasar 1945 pasal 1 ayat 3 "Indonesia Adalah Negara hukum".

Pandangan saya didasarkan pada asumsi bahwa setiap tindakan atau praktik menyiratkan, baik secara implisit maupun eksplisit, sebuah teori; karena setiap praktik pada dasarnya merupakan sebuah abstraksi dari teori atau yang akan diabstracksikan menjadi sebuah teori. Sebagaimana yang dikemukakan John Friedmann (1998: 250) bahwa: 'Salah satu mitos yang masih ada di antara para pakar praktis adalah bahwa mereka tidak membutuhkan teori. Namun, pada kenyataannya praktisi terus-menerus bekerja dengan asumsi teoritis. Intinya adalah bukan begitu banyak sehingga praktisi adalah ahli teori nyata (Bolan, 1980); itu adalah bahwa teori bukanlah hal-hal abstrak yang relevan bagi para akademisi saja, tetapi untuk semua orang. Bahkan, apa yang disebut celah teoripraktik (theory and practice gaps) bukanlah masalah utama. Secara sederhana, pertanyaan sebenarnya adalah teori apa untuk jenis latihan apa?

Dengan asumsi pandangan ini, dalam artikel ini saya akan menyajikan dua teori yang berbeda (atau, mungkin, meta-teori) dari peraturan publik: pendekatan 'teleokratis' dan pendekatan 'nomokratis'. Mereka dapat diartikan sebagai pendekatan mengenai peran umum negara dalam mengatur tindakan individu, tetapi di sini saya akan fokus terutama pada konsekuensi dari menerima mereka di bidang spesifik peraturan penggunaan lahan. Seperti yang akan kita lihat, untuk perencanaan pendekatan teleokratis harus menjadi instrumen utama dan paling penting dari peraturan penggunaan lahan publik 
sementara untuk perencanaan pendekatan nomokrat hanya memiliki peran sekunder dan berbagai jenis instrumen regulatif yang diusulkan.

Saya tidak bermaksud mengusulkan dikotomi dalam arti sempit antara pendekatan teleokratis dan nomokratis. Pada dasarnya, sementara kedua pendekatan tersebut kontras dan yang satu tidak dapat direduksi menjadi yang lain, keduanya tidak menyeluruh secara keseluruhan; memang, pendekatan lain dapat diidentifikasi atau ditenderkan. Yang ingin saya katakan adalah bahwa kuota luas teori perencanaan dan praktik berasal dari pendekatan teleokratis, dan bahwa pendekatan nomokratik menawarkan alternatif menarik di antara pilihan-pilihan yang tersedia bagi kita.

Jelas, dalam ruang terbatas sebuah artikel, beberapa penyederhanaan diperlukan dalam menjabarkan dua pendekatan; tetapi, menurut saya, inti dari pertanyaan itu cukup jelas tanpa beralih ke kehalusan atau detail yang lebih luas. Satu komentar terakhir diperlukan sebelum saya melanjutkan. Di sini saya berniat 'merencanakan' sebagai suatu kegiatan — kegiatan yang dimaksudkan untuk menjadi rasional - yang membayangkan keadaan yang diinginkan, dan mengatur tindakan untuk mencapai keadaan itu. Dan saya mengacu pada 'perencanaan publik' ketika ada otoritas yang memegang kekuatan hukum untuk menegakkan kontrol dan peraturan untuk memandu tindakan pemerintah dalam arah yang diinginkan publik.

Ide nomokrasi Islam untuk Indonesia ini diawali atau diinspirasikan oleh Pemerintah Aceh yang telah melakukan penataan perangkat Aceh dengan ditetapkannya sejumlah Qanun dan Peraturan Gubernur, namun sejalan dengan perkembangan penyelenggaraan pemerintahan dan pembangunan masih terdapat kendala dan hambatan dalam pelaksanaan penataan perangkat daerah. Permasalahan tersebut meliputi: Pola besaran organisasi tidak sesuai dengan urusan/kewenangan, kemampuan, kebutuhan, potensi dan karakteristik daerah. Pelaksanaan urusan pemerintahan dalam satu kelembagaan perangkat daerah menyebabkan kesulitan dalam melakukan koordinasi baik dengan Pemerintah maupun dengan Pemerintah Kabupaten/Kota. Sistem demokrasi telah memunculkan pembangkangan aparatur (state-craft disobedience) negara yang lebih rendah karena memiliki otoritas dari rakyat setelah dipilih melalui pemilu 
demokrasi. Negara pusat pun memiliki cara-cara tidak etis untuk menangkap dan memenjarakan aparatur negara yang dipilih melalui pemilu demokrasi lokal dengan tuduhan-tuduhan korupsi dan penyimpangan lainnya.

Konsep tatanan spontan dan ideal aturan hukum sederhananya kita dapat mengatakan bahwa itu tidak mungkin dan tidak diinginkan untuk (secara otoritatif) merencanakan sistem sosial yang kompleks (sistem yang kompleks adalah sistem yang memiliki jumlah yang sangat besar — beribu komponen, menyajikan interaksi non-linear di antara komponen-komponen tersebut, polapola yang tidak sengaja muncul, mengorganisir diri, dinamis dan adaptif). Kota, negeri atau negara inilah yang kemudian melahirkan kesadaran politik (politiekbewust) bagi warganya (Kartosoewirjo, 1946: 7). Dan kota-kota adalah sistem yang sangat kompleks, karena mereka tidak dapat diprediksi, sistem dinamis berdasarkan hubungan kausal non-linear yang tak terhitung banyaknya (Portugali, 1999, 2008). Kedua, 'kota tumbuh terutama dari tindakan berdasarkan keputusan individu tentang pengembangan yang dibuat secara lokal, kota-kota tidak berkembang secara ketat sesuai dengan rencana besar apa pun. Mereka terlalu rumit dan beragam untuk dikendalikan, terlalu heterogen dan responsif terhadap lingkungan yang lebih luas untuk dikelola dalam totalitas mereka (Batty, 2005: 515). Ketiga, banyaknya elemen yang membentuk sistem kompleks seperti kota 'membentuk jaringan kompleks yang ditandai oleh fenomena umpan balik dan loop umpan ke depan dan karena itu sulit diprediksi atau diatur' (Alfasi dan Portugali, 2007: 168). 'Karena sifatnya sebagai sistem yang mengatur dirinya sendiri, kota tidak dapat diprediksi, tidak dapat dikendalikan dan dalam hal ini tidak dapat diperbaiki' (Portugali, 1999: 230). Singkatnya, semakin kompleks sistem sosial, perencanaan yang kurang bermanfaat (publik) akan terjadi (Kasper 2010; Webster dan Lai, 2003). Ini benar, baik untuk perencanaan imperatif maupun untuk perencanaan fleksibel.

Pertanyaan utama, oleh karena itu, tidak begitu banyak apakah pengaruh teori praktik - ini jelas dan tak terelakkan, karena setiap praktik kurang lebih secara implisit mengasumsikan teori - tetapi teori mana yang paling berguna dan diinginkan. Saya percaya bahwa agar relevan saat ini, teori tata guna lahan yang bermanfaat dan diinginkan harus berlawanan dengan intuisi: ia perlu dipusatkan, 
dari sudut pandang empiris, sekitar gagasan paradoksis tentang tatanan spontan (yaitu urutan tindakan yang muncul tanpa disengaja dan mengorganisir diri: Moroni, 2010) dan, dari sudut pandang normatif, pada penemuan kembali ideal aturan hukum dalam versi radikal dan kuat (yaitu ideal yang menempatkan kebebasan individu di bawah hukum impersonal dan tidak resmi di pusat perhatian: Moroni, 2007).

Aceh atau Nanggroe Aceh yang kini lebih dikenal dengan Serambi Mekkah merupakan salah satu wilayah Indonesia yang dihadiahkan pemberlakuan otonomi daerah secara khusus oleh Pemerintah Indonesia dimana sistem hukum Islam diterapkan secara distingtif. Dalam konteks ilmu Tata Negara, Aceh seperti sebuah negara di dalam lingkup negara Indonesia, dibuktikan dengan adanya UUPA didalam Undang-undang yang berlaku di Indonesia sekarang ini. Hal ini tidak lepas dari secara historis dan politik yang telah terjadi beberapa waktu silam di Indonesia ini. Yang berdampak pada pemberlakuan Syari'at Islam di bumi Aceh. Syari'at Islam merupakan sebuah sistem hukum Islam layaknya sistem hukum lainnya, yang mencakup; perdata, pidana, dagang, keluarga, peradilan dan sebagainya. Pelaksaan dan pemberlakuan syari'at Islam di Aceh ini sesuai dengan adat kebiasaan yang telah ada dan belaku serta berkembang sejak lama dari masa perjuangan melawan penjajah sampai sekarang ini, melahirkan UU No. 18 Tahun 2001 tentang status otonomi khusus untuk Aceh yang kemudian pula terhapuskan oleh UU No. 11 Tahun 2006 tentang Pemerintahan Aceh.

Undang- undang No. 11 Tahun 2006 tentang Pemerintahan Aceh menegaskan bahwa Syari'at Islam yang dilaksanakan di Aceh meliputi aqidah, syari'ah dan akhlak (Pasal 125 ayat (1)). Syariat Islam tersebut meliputi ibadah, ahwal al-syakhshiyah (hukum keluarga), muamalah (hukum perdata), jinayah (hukum pidana), qadha' (peradilan), tarbiyah (pendidikan), dakwah, syiar, dan pembelaan Islam. Ketentuan mengenai pelaksanaan Syariat Islam diatur dengan Qanun. ${ }^{1}$ Adapun yang dimaksud dengan Qanun, dalam Pasal 1 angka 8 UU No. 18

${ }^{1}$ Qanun berasal dari bahasa Arab yang diartikan sebagai "peraturan", penyebutan atau nama lain dari Peraturan Daerah (Perda), lebih jauh Qanun Aceh adalah peraturan perundang-undangan sejenis peraturan daerah provinsi yang mengatur penyelenggaraan pemerintahan dan masyarakat Aceh, (Undang-Undang Nomor 11 tahun 2006, Bab I Ketentuan Umum, Pasal 1 ayat 21). 
Tahun 2001, dikatakan bahwa Qanun Aceh adalah Peraturan Daerah sebagai pelaksanaan undang-undang di wilayah Aceh dalam rangka penyelenggaraan otonomi khusus (Armia Ibrahim, 2001: 2). Jadi, Qanun adalah peraturan daerah provinsi yang mengatur penyelenggaraan pemerintahan dan kehidupan masyarakat Aceh. Qanun dapat mengenyampingkan peraturan perundangundangan yang lain dengan mengikuti asas lex specialis derogaat lex generalis dan MA berwenang melakukan uji materil terhadap Qanun (Puteri Hikmawati, 2008: 71).

Diberlakukannya UUPA (Undang-undang Pemerintahan Aceh) adalah entry point karena telah memberi kewenangan bagi pemerintah untuk mengatur tata pemerintahan yang lebih mandiri. Baik kewenangan menentukan sistim politik, birokrasi, ekonomi maupun sosial budaya masyarakat Aceh. UUPA memberi ruang untuk menentukan identitas Aceh secara khas. Syari'at Islam yang sedang diterapkan sejatinya adalah acuan untuk mengembalikan ruh dan jadi diri masyarakat Aceh itu sendiri, sehingga diperlukan pengelolaan yang benar dan baik oleh seluruh stakeholders untuk kemajuan Aceh masa depan karena Syariat Islam bukan sekedar image dengan slogan-slogan, tapi juga membangun sistim dan kualitas umatnya.

Dalam konteksnya, UU Nomor 44 Tahun 1999 tentang Pelaksanaan Keistimewaan Aceh dan UU Nomor 11 Tahun 2006 tentang Pemerintahan Aceh, mengamanahkan pelaksanaan syariat Islam secara kaffah(totalitas) dari perkara ibadah (hablum minallah), muamalah (hablum minannas), syiar, pendidikan, jinayah (hukum pidana) sampai kepada perkara dusturiah (qanun atau konstitusi). Pada tahun 2001 Pemerintah mendeklarasikan Aceh sebagai wilayah syariat Islam. Pendeklarasian ini memunculkan dua fenomena yaitu menantang dan menarik. Yang paling menantang adalah kesiapan pemerintah, individu dan masyarakat muslim Aceh untuk melaksanakan Syariat Islam dan menariknya adalah karena Aceh menjadi satu-satu daerah yang menerapkan hukum yang relatif berbeda dengan sistim hukum nasional.

Pada dasarnya salah satu bentuk format otonomi khusus Aceh adalah implementasi Syariat Islam yang kemudian dibentuknya beberapa lembaga untuk menjalankannya, yaitu: Mahkamah Syariah, Majelis Permusyawaratan Ulama, 
Dinas Syariat Islam, Wilayatul Hisbah, serta Badan Pembinaan dan Pendidikan Dayah (pesantren). Pelaksanaan kelembagaan birokrasi ini dalam konteks kebangsaan, belum ada contoh di tempat lain kecuali baru diterapkan di Aceh walaupun polanya masih mencari bentuk yang ideal. Maka akan terus diuji melalui diskursus dan kritik agar pelaksanaan ke depan akan lebih baik. Urgensi Birokrasi yang berkarakter Syari'at tidak hanya dalam bentuk hukum (qanun) namun harus sampai pada perilaku birokrasi yang Islami. Yaitu birokrasi yang mampu menunjukkan semangat kebijakan pelaksanaan syariah Islam itu sendiri. Mulai dari pelayanan birokrasi yang murni berorientasi pada kemaslahatan publik bukan pada kepentingan kapitalistik atau mengutamakan orang yang bermodal. Perilaku buruk yang sudah berlangsung lama dalam pemerintahan Aceh, seperti, program pembangunan yang hanya menghabiskan uang, kurang terserapnya anggaran serta pembangunan tidak tepat sasaran (Tim Terpadu Percepatan Pemerintahan Aceh 2012-2016).

\section{B. Kultur dan Struktur Birokrasi dalam Negara}

Selama ini, para pegawai pemerintah hidup dalam keistimewaan dan perlakuan khusus dari negara. Para ambtenaar atau pegawai negeri menikmati banyak keistimewaan karena memiliki hirarki yang mapan dengan gaji tetap dan fasilitas kantor yang nyaman. Terdapat tiga hal yang merupakan kesenjangan antara das sein (realitas) dan das sollen (yang ideal) yang kemudian dicoba untuk dipecahkan dalam penelitian ini. Kesenjangan tersebut bersifat teoritis serta empiris. Pertama, penelitian ini berusaha untuk memperkaya minimnya kajian teoritis yang mengkaitkan antara struktur organisasi dengan manajemen pengetahuan terutama terkait dengan penciptaan serta transfer pengetahuan. Kedua, penelitian ini mencoba menutupi kesenjangan teoritis terkait dengan manajemen pengetahuan serta arahanarahan politis yang sebenarnya sangat dominan di sektor pemerintahan. Ketiga, penelitian ini akan secara empiris memetakan mengenai manajemen pengetahuan di lingkungan Pemerintahan Aceh yang tengah bersemangat dengan syariat Islam yang sangat nomokratis ini.

Latar belakang masalah di atas memberikan gambaran permasalahan yang dapat diidentifikasikan tentang Kebijakan reformasi birokrasi Pemerintahan Aceh 
yang berkarakter Syariat Islam sebagai berikut: (1) Konsep nomokrasi dalam birokrasi di sebuah negara hukum sangat ditentukan oleh kultur dan sejarah birokrasi suatu daerah. Khusus untuk Aceh, sistem nomokrasi adalah sistem yang sudah mengakar kuat di Aceh. Kurangnya muatan kebijakan yang mengatur tentang pelaksanaan birokrasi berkarakter Syariat Islam di Pemerintahan Aceh tentang lima kelembagaan tersebut di atas; (2) Aktor kebijakan belum mampu memaknai konten kebijakan tersebut. Ada beberapa kesenjangan pengetahuan para pemangku kebijakan (stake-holders) yang dilihat dalam penelitian ini yang masih sangat jauh dari idealitas birokrasi yang modern dan netral; (3) Perilaku birokrat atau struktur birokrasi sebagai pelaksanaan implementasi kebijakan serta sumber daya yang ada merupakan faktor hambatan dalam pelaksanakannya. Perilaku birokrat tidak sinkron dengan teknokrat Aceh dan para intelektual organik Aceh yang sudah mengidealisasi syariat Islam secara kenegaraan.

Teori perencanaan memiliki pengaruh yang kecil terhadap praktik perencanaan. Beberapa orang berbicara tentang 'celah praktik-teori' yang jelas (Slaev, 2018: 301). Kenyataannya, yang terjadi justru sebaliknya. Yang disebut 'celah theory practice' bukanlah masalah utama sama sekali; pertanyaan sebenarnya adalah 'teori apa untuk jenis latihan apa'? Dengan asumsi pandangan ini, artikel ini menyajikan dua teori yang berbeda dari peraturan publik: pendekatan teleokratis dan pendekatan nomokratik. Mereka dapat diartikan sebagai pendekatan umum mengenai peran negara, tetapi artikelnya fokus terutama pada konsekuensi menerima mereka dalam spesifik. bidang peraturan penggunaan lahan. Untuk pendekatan teleokratis, perencanaan harus menjadi instrumen utama dan paling penting dari peraturan penggunaan lahan, sedangkan untuk perencanaan pendekatan nomokratik hanya memiliki peran sekunder dan berbagai jenis instrumen regulatif yang diusulkan.

Berdasarkan latar belakang masalah yang telah diuraikan di atas terdapat dua persoalan utama yang diteliti dalam banyak penyelidikan, yaitu: (1) Bagaimana kaum intelektual organik Aceh dalam merumuskan reformasi birokrasi dari yang sekuler ke reformasi birokrasi yang nomokratis (bersyariat) di Aceh. Banyak muatan pemikiran mereka yang belum tertuang dalam sejumlah kebijakan birokratik di Aceh. Bagaimanakah konten (isi atau muatan) kebijakan yang 
mengatur tentang lima kelembagaan tersebut sudah mencerminkan pelaksanaan reformasi birokrasi berkarakter Syariat Islam di Pemerintahan Aceh? (2) Penerjemahan pengetahuan nomokratik syariat Islam di Aceh ke dalam langkahlangkah konkrit reformasi birokrasi masih sangat sedikit, untuk menyebut ketiadaan pemikiran reformatif sama sekali dalam sistem politik di Aceh. Apakah aktor kebijakan telah mampu memaknai konten kebijakan tersebut? Serta bagaimanakah hambatan dalam mengimplementasikan kebijakan reformasi birokrasi berkarakter Syariat Islam, apakah faktor perilaku birokrat atau struktur birokrasi sebagai penghambat pelaksanaan implementasi kebijakan tersebut ataukah sumber daya yang ada belum mampu melaksanakannya?

Dalam sejarah penyelenggaraan pemerintahan daerah di Indonesia, tercatat beberapa daerah yang memiliki otonomi khusus dengan sebutan yang berbedabeda sesuai dengan latar belakang sejarah pembentukan dan kebijakan otonomi daerah yang mengatur pada masanya, misalnya pada masa diberlakukannya Undang-undang Nomor 5 Tahun 1974 dikenal istilah 'Daerah Istimewa' untuk menyebut Daerah Istimewa Aceh dan Daerah Istimewa Yogyakarta. Kemudian sebutan Daerah Khusus lbukota Jakarta' untuk menyebut status khusus Jakarta sebagai lbukota Negara. Namun kini semua potensi legal daerah tergerus oleh dominasi legal negara setelah disetujuinya omnibus law di Indonesia dimana banyak pemerintahan daerah (propinsi) tidak lagi memiliki kekuasaan mutlak atas sumberdaya lokalnya.

Dulu, ada jabatan Wali Neugara yang dijabat sebagai pengganti sebelum dewasanya Sultan Alaidinsyah dan Sultan Mahmudsyah. Sebelum kedua sultan itu dewasa mereka memiliki wali, dan itulah yang disebut wali negara (Wali Nanggroe). Aceh ini nanti akan menjadi negara yang mandiri, jadi mulai sekarang harus mempersiapkan sebuah jabatan yang khusus ke depan. Apalagi Aceh tidak lagi dipimpin oleh seorang sultan. WN yang tepat adalah seorang yang paham tentang syariah, siasat, politik, dan juga paham tentang hukum negara, paham sejarah Aceh, paham antara demokrasi dan nomokrasi. Karena negara Aceh yang kita rencanakan ke depan adalah negara nomokrasi bukan demokrasi (www.ajnn.net, 11 Desember 2018). 
Sering disebutkan bahwa teori perencanaan memiliki pengaruh yang kecil terhadap praktik perencanaan. Beberapa orang berbicara tentang 'celah praktikteori' yang jelas (Slaev, 2018: 301). Kenyataannya, yang terjadi justru sebaliknya. Yang disebut 'celah theory practice' bukanlah masalah utama sama sekali; pertanyaan sebenarnya adalah 'teori apa untuk jenis latihan apa'? Penelitian Slaev ini berkontribusi pada perdebatan tentang sifat perencanaan dalam sistem yang kompleks, dan khususnya teori teleokrasi (pendekatan berdasarkan ketentuan langsung yang ditujukan pada tujuan tertentu) dan nomokrasi (pendekatan berdasarkan aturan yang ditujukan untuk tujuan umum dan bukan tujuan khusus). Ini menarik kesejajaran dengan teori regulasi dan menetapkan hubungan antara aturan, regulasi dan perencanaan nomokratik kegiatan sosial. Kemudian menyarankan bahwa analisis hak milik dari bentuk-bentuk koordinasi / organisasi sosial dapat menjadi instrumen dalam memahami sifat interaksi sosial. Berdasarkan teori hak milik, penelitian ini menyimpulkan bahwa penggunaan berbagai jenis perencanaan, regulasi atau mekanisme pasar koordinasi sosial sangat erat kaitannya dengan bentuk kepemilikan konkrit atas sumber daya yang digunakan dalam kegiatan sosial tertentu (Slaev, 2016: 274).

Dengan asumsi pandangan ini, artikel ini menyajikan dua teori yang berbeda dari peraturan publik: pendekatan teleokratis dan pendekatan nomokratik. Mereka dapat diartikan sebagai pendekatan umum mengenai peran negara, tetapi artikelnya fokus terutama pada konsekuensi menerima mereka dalam spesifik. bidang peraturan penggunaan lahan. Untuk pendekatan teleokratis, perencanaan harus menjadi instrumen utama dan paling penting dari peraturan penggunaan lahan, sedangkan untuk perencanaan pendekatan nomokratik hanya memiliki peran sekunder dan berbagai jenis instrumen regulatif yang diusulkan. ${ }^{2}$

Ringkasnya, A government based on the supremacy of the law is called a nomocracy. Aturan hukum adalah "otoritas dan pengaruh hukum dalam masyarakat, terutama ketika dilihat sebagai kendala pada perilaku individu dan kelembagaan; (karenanya) prinsip di mana semua anggota masyarakat (termasuk yang di pemerintahan) dianggap sama (aturan akan, mengacu pada undang-

${ }^{2}$ https://www.researchgate.net/publication/258179130_Rethinking_the_theory_and_practic e_of_land-use_regulation_Towards_nomocracy [diakses 10 Sep 2018]. 
undang yang ditukarkan dengan yang terendah, di masyarakat) tunduk pada kode dan proses hukum yang diungkapkan secara terbuka. Frasa "aturan hukum" mengacu pada situasi politik, bukan pada aturan hukum tertentu. Penggunaan frasa ini dapat ditelusuri kembali ke abad ke-16 di Inggris, dan pada abad berikutnya, teolog Skotlandia Samuel Rutherford menggunakannya dalam memperdebatkan hak ilahi para raja. John Locke menulis bahwa kebebasan dalam masyarakat berarti hanya tunduk pada undang-undang yang dibuat oleh legislatif yang berlaku untuk semua orang, dengan orang yang dinyatakan bebas dari pembatasan baik pemerintah maupun swasta atas kebebasan. "Aturan hukum" lebih dipopulerkan pada abad ke-19 oleh ahli hukum Inggris A. V. Dicey (2013). Namun, prinsipnya, jika bukan frasa itu sendiri, diakui oleh para pemikir kuno; misalnya, Aristoteles menulis: "Adalah lebih tepat bahwa hukum harus mengatur setidaknya salah satu warga negara" agar hukum memiliki makna yang signifikan untuk hadir di tengah masyarakat.

Aturan hukum menyiratkan bahwa setiap orang tunduk pada hukum, termasuk orang-orang yang merupakan anggota parlemen, pejabat penegak hukum, dan hakim. Dalam pengertian ini, ia bertentangan dengan otokrasi, kediktatoran, atau oligarki di mana para penguasa dipegang di atas hukum. Kekurangan aturan hukum dapat ditemukan baik di demokrasi dan kediktatoran, misalnya karena kelalaian atau ketidaktahuan hukum, dan aturan hukum lebih tepat untuk membusuk jika pemerintah memiliki mekanisme korektif yang tidak cukup untuk memulihkannya. Meskipun kredit untuk mempopulerkan ekspresi "aturan hukum" di zaman modern biasanya dinisbatkan kepada AV Dicey (2013), pengembangan konsep hukum dapat ditelusuri melalui sejarah ke banyak peradaban kuno, termasuk Yunani kuno, Cina, Mesopotamia, India, dan Roma.

Di Barat, orang Yunani kuno awalnya menganggap bentuk pemerintahan terbaik sebagai aturan oleh orang-orang terbaik. Plato menganjurkan monarki yang baik hati yang diperintah oleh raja filsuf yang diidealisasikan, yang berada di atas hukum. Plato tetap berharap bahwa orang-orang terbaik akan pandai menghormati hukum yang mapan, menjelaskan bahwa "Di mana hukum tunduk pada beberapa otoritas lain dan tidak milik sendiri, runtuhnya negara, dalam pandangan saya, tidak jauh, tetapi jika hukum adalah penguasa pemerintah dan 
pemerintah adalah budaknya, maka situasinya penuh dengan janji dan orangorang menikmati semua berkat yang dewa-dewa mandi pada negara. "Lebih dari Plato berusaha untuk melakukannya, Aristoteles menentang mentah-mentah, membiarkan pejabat tertinggi memegang kekuasaan di luar menjaga dan melayani hukum. Dengan kata lain, Aristoteles (dalam Peters, 1968: 7) menganjurkan aturan hukum:

Adalah tepat bahwa hukum harus mengatur minimal salah satu warga negara: atas prinsip yang sama, jika menguntungkan untuk menempatkan kekuasaan tertinggi pada beberapa orang tertentu, mereka harus ditunjuk hanya sebagai wali, dan hamba hukum. Negarawan Romawi, Cicero (2001) sering dikutip, kira-kira, "Kami semua adalah pelayan hukum agar bebas." Selama Republik Romawi, para hakim kontroversial mungkin akan diadili ketika masa jabatan mereka berakhir. Di bawah Kekaisaran Romawi, kedaulatan secara pribadi kebal (legibus solutus), tetapi orang-orang dengan keluhan bisa menuntut perbendaharaan. Di Cina, anggota sekolah legalisme selama abad ke-3 SM berpendapat untuk menggunakan hukum sebagai alat pemerintahan, tetapi mereka mempromosikan "aturan oleh hukum" sebagai lawan "aturan hukum", yang berarti bahwa mereka menempatkan bangsawan dan kaisar di atas hukum. Sebaliknya, sekolah Taoisme Huang-Lao menolak positivisme hukum demi hukum alam yang bahkan penguasa akan tunduk.

Baru-baru ini ada upaya untuk mengevaluasi kembali pengaruh Alkitab terhadap hukum konstitusional Barat. Dalam Perjanjian Lama, kitab Ulangan menetapkan pembatasan tertentu pada raja, mengenai hal-hal seperti jumlah istri yang mungkin dia ambil dan kuda yang mungkin dia peroleh (untuk digunakan sendiri). Menurut Profesor Bernard M. Levinson (2002), "Perundang-undangan ini sangat utopis di zamannya sendiri yang tampaknya tidak pernah dilaksanakan ...." Visi sosial Deuteronomis mungkin telah memengaruhi lawan-lawan dari hak ilahi para raja, termasuk Uskup John Ponet di Inggris abad ke-16. Dalam aturan hukum yurisprudensi Islam dirumuskan pada abad ketujuh, sehingga tidak ada pejabat yang bisa mengklaim berada di atas hukum, bahkan khalifah. Namun, ini bukan referensi untuk hukum sekuler, tetapi hukum agama Islam dalam bentuk hukum Syariah. 
Alfred the Great, raja Anglo-Saxon pada abad ke-9, mereformasi hukum kerajaannya dan menyusun sebuah kode hukum (Kitab Doom) yang dia tegaskan pada perintah-perintah alkitabiah. Dia berpendapat bahwa hukum yang sama harus diterapkan pada semua orang, apakah kaya atau miskin, teman atau musuh. Hal ini mungkin diilhami oleh Imamat 19:15: "Janganlah kamu berbuat jahat dalam penghakiman. Kamu tidak akan menyukai orang celaka dan kamu tidak akan tunduk kepada orang kaya. Dalam kebenaran, kamu harus menghakimi sesamamu." Pada tahun 1215, Uskup Agung Stephen Langton mengumpulkan para Baron di Inggris dan memaksa Raja John dan penguasa masa depan dan hakim kembali di bawah kekuasaan hukum, melestarikan kebebasan kuno oleh Magna Carta dengan imbalan menuntut pajak. Landasan konstitusi ini dibawa ke dalam Konstitusi Amerika Serikat (Ottenberg, 1957).

Pada tahun 1481, pada masa pemerintahan Ferdinand II dari Aragon, Constitució de l'Observança disetujui oleh Pengadilan Umum Catalonia, menetapkan pengajuan kekuasaan kerajaan (termasuk para petugasnya) kepada hukum-hukum Kerajaan Catalonia (Fornaciari, 2009: 671). Penggunaan pertama yang diketahui dari frasa bahasa Inggris ini terjadi sekitar 1500 AD. Contoh awal lain dari frasa "aturan hukum" ditemukan dalam petisi kepada James I dari Inggris pada 1610, dari House of Commons:

Di antara banyak hal lain tentang kebahagiaan dan kebebasan yang telah dinikmati oleh para leluhur Kita di kerajaan ini di bawah leluhur Kita, raja dan ratu di dunia ini, tidak ada satu pun yang lebih berharga dan berharga daripada ini, untuk dibimbing dan diatur oleh aturan hukum tertentu yang memberikan kepada kepala dan anggota apa saja hak milik mereka, dan bukan oleh bentuk pemerintahan yang tidak pasti atau sewenang-wenang ....

Pada tahun 1607, Hakim Agung Inggris Sir Edward Coke mengatakan dalam Kasus Larangan (menurut laporannya sendiri) "bahwa undang-undang itu adalah tongkat emas dan ukuran untuk mencoba penyebab mata pelajaran dan yang melindungi Yang Mulia dengan aman dan perdamaian dengan mana sang Raja sangat tersinggung (Boyer, 1997). Dan berkata, bahwa ia harus berada di bawah hukum, yang merupakan pengkhianatan untuk diteguhkan, seperti yang ia katakan "yang saya katakan, bahwa Bracton berkata dan berdalih Rex non debet esse sub 
homin sub Deo et lege (Bahwa Raja seharusnya tidak berada di bawah pria atau wanita mana pun kecuali di bawah Tuhan dan hukum)."

Di antara penulis modern pertama yang menggunakan istilah tersebut dan memberikan landasan teoritis prinsipnya adalah Samuel Rutherford dalam Lex, Rex (1644). Judulnya, bahasa Latin untuk "hukum adalah raja", mendekonstruksi formulasi tradisional rex lex ("raja adalah hukum") (Coffey, 1997). James Harrington (1737) membahas tentang Politik Aristoteles bahwa di antara bentukbentuk pemerintahan, "Kekaisaran Hukum, dan bukan Manusia" lebih disukai daripada "Kekaisaran Manusia, dan bukan Hukum". John Locke (1794) membahas masalah ini dalam Second Treatise of Government:

Kebebasan alami manusia adalah bebas dari segala kekuatan superior di bumi, dan tidak berada di bawah kehendak atau otoritas legislatif manusia, tetapi hanya memiliki hukum alam untuk pemerintahannya. Kebebasan manusia dalam masyarakat tidak berada di bawah kekuasaan legislatif lain, tetapi yang didirikan dengan persetujuan dalam persemakmuran dan tidak berada di bawah kekuasaan kehendak apa pun atau pengekangan hukum apa pun, tetapi apa yang akan diberlakukan legislatif untuk mengatur kepercayaan yang diletakan di dalamnya.

Kebebasan bagi setiap orang untuk melakukan apa yang dia lakukan selama hidup sesuai keinginannya, dan tidak terikat oleh hukum apa pun. Tetapi kebebasan manusia di bawah pemerintahan adalah untuk memiliki aturan untuk hidup setiap masyarakat dan dibuat oleh kekuasaan legislatif yang didirikan di dalamnya. Kebebasan untuk mengikuti kehendak seseorang dalam segala hal, di mana aturan tidak menentukan dan tidak tunduk pada kehendak yang tidak tentu, tidak pasti, tidak diketahui, dan sewenang-wenang dari orang lain. sebagaimana kebebasan alam yang berada di bawah batasan pengendalian lain selain hukum alam. Prinsip ini juga dibahas oleh Montesquieu dalam The Spirit of the Laws (1748 [1949]). Frasa "aturan hukum" muncul dalam Samuel Johnson Dictionary (1850) yang kemudian menjadi sangat populer dan mempengaruhi banyak negara untuk mewujudkan hukum yang pasti dan adil.

Pada 1776, gagasan bahwa tidak ada seorang pun di atas hukum populer selama berdirinya Amerika Serikat. Sebagai contoh, Thomas Paine menulis dalam pamflet berjudul Common Sense bahwa "di Amerika, hukum adalah raja. Karena 
seperti dalam pemerintahan absolut sang Raja adalah hukum, jadi di negaranegara bebas hukum harus menjadi raja dan seharusnya tidak ada yang lain. Pada 1780, John Adams mengabadikan prinsip ini dalam Konstitusi Persemakmuran Massachusetts dengan mencari untuk menetapkan "pemerintah hukum dan bukan manusia" (Witte 2004).

Pengaruh Inggris, Prancis, dan Amerika Serikat berkontribusi dalam menyebarkan prinsip supremasi hukum ke negara-negara lain di seluruh dunia. Kamus Bahasa Inggris Oxford telah mendefinisikan "aturan hukum" seperti Wewenang dan pengaruh hukum dalam masyarakat. Khususnya ketika dilihat sebagai kendala pada perilaku individu dan kelembagaan. Karena itu, prinsip di mana semua anggota masyarakat (termasuk mereka yang berada di pemerintahan) dianggap sama tunduk pada hukum dan proses hukum yang diungkapkan secara terbuka (Bingham, 2011).

Rule of law mengimplikasikan bahwa setiap warga negara tunduk pada hukum. Ini bertentangan dengan gagasan bahwa penguasa berada di atas hukum, misalnya oleh hak ilahi. Meskipun banyak digunakan oleh politisi, hakim dan akademisi, supremasi hukum telah digambarkan sebagai "gagasan yang sangat sulit dipahami". Di antara para ahli teori hukum modern, orang menemukan bahwa setidaknya dua konsepsi utama dari aturan hukum yang dapat diidentifikasi: definisi formalis atau "tipis", dan definisi substantif atau "tebal", kadang-kadang menemukan konsepsi "fungsional" (Tamanah, 2004).

Definisi formalis yang mengatur hukum dengan tidak membuat penilaian tentang "keadilan" hukum itu sendiri, tetapi menentukan atribut prosedural spesifik yang harus dimiliki kerangka hukum agar sesuai dengan aturan hukum. Konsepsi substantif dari aturan hukum yang melampaui yang didasarkan pada atau berasal dari supremasi hukum (Carrother, 1998). Rasa keadilan masyarakat atas terjadinya tindakan pidana tertentu akan merugikan banyak orang yang akhirnya akan berkesimpulan bahwa hukum negara tidak adil untuk rakyatnya. ${ }^{3}$

Sebagian besar ahli teori hukum percaya bahwa aturan hukum memiliki karakteristik formal murni, yang berarti bahwa hukum harus diumumkan secara

\footnotetext{
${ }^{3}$ Lihat tentang hal ini: "Negara, Islam dan Nasionalisme | Al Chaidar | download." https://bok.cc/book/2719895/900473.
} 
terbuka (larangan atau urgensi), dengan penerapan prospektif (hukuman atau konsekuensi yang terkait dengan larangan atau urgensi tertentu), dan memiliki karakteristik umum (biasanya berarti konsistensi dan komprehensibilitas), kesetaraan (yang diterapkan secara merata di seluruh masyarakat), dan kepastian (yaitu, kepastian penerapan untuk situasi tertentu), tetapi tidak ada persyaratan yang berkaitan dengan isi undang-undang. Yang lain, termasuk beberapa ahli teori hukum, percaya bahwa aturan hukum harus mencakup perlindungan hak-hak individu. Dalam teori hukum, kedua pendekatan ke aturan hukum dilihat sebagai dua alternatif dasar, masing-masing diberi label pendekatan formal dan substantif. Tetapi ada beberapa pandangan lain yang percaya bahwa demokrasi adalah bagian dari aturan hukum (Scalia, 1989).

Interpretasi "formal" lebih luas daripada interpretasi "substantif". Kaum Formalis atau para pengusung hukum legal-formal berpendapat bahwa hukum harus prospektif, terkenal, dan memiliki karakteristik umum, kesetaraan, dan kepastian. Selain itu, pandangan formal tidak mengandung persyaratan untuk isi undang-undang. Pendekatan formal ini memungkinkan undang-undang yang melindungi demokrasi dan hak-hak individu, tetapi mengakui keberadaan "aturan hukum" di negara-negara yang belum tentu memiliki hukum yang melindungi demokrasi atau hak-hak individu. Interpretasi substantif menyatakan bahwa aturan hukum secara intrinsik melindungi sebagian atau semua hak individu. Sementara, interpretasi fungsional dari "aturan hukum" hanya melindungi atau mereduksi perlindungan untuk sebagian bidang dan sektor tertentu saja (Radin, 1989).

Menurut pandangan fungsional, masyarakat di mana para pejabat pemerintah yang memiliki banyak kebijaksanaan memiliki tingkat "aturan hukum" yang rendah, sedangkan masyarakat di mana para pejabat pemerintah yang memiliki sedikit kebijaksanaan memiliki "aturan hukum" tingkat tinggi. Menegakkan aturan hukum terkadang dapat membutuhkan hukuman bagi mereka yang melakukan pelanggaran yang dapat dibenarkan di bawah hukum kodrat tetapi bukan hukum yang berlaku. Dengan demikian, rule of law agak bertentangan dengan fleksibilitas (Fallon, 1997). 
Konsep kuno negara hukum dapat dibedakan dari aturan hukum, menurut profesor ilmu politik Li Shuguang: "Perbedaan ... adalah bahwa, di bawah kekuasaan hukum, hukum adalah yang terbaik dan dapat berfungsi sebagai pemeriksaan terhadap penyalahgunaan kekuasaan. Di bawah aturan hukum, undang-undang hanyalah alat bagi pemerintah, yang menekan dengan cara legalistik" (Peereenboom, 2002).

Aturan hukum telah dianggap sebagai salah satu dimensi kunci yang menentukan kualitas dan tata pemerintahan yang baik dari suatu negara. Penelitian, seperti Indikator Tata Kelola Seluruh Dunia, mendefinisikan aturan hukum sebagai: "sejauh mana agen memiliki kepercayaan diri dan mematuhi aturan masyarakat, khususnya kualitas penegakan kontrak, polisi dan pengadilan, serta kemungkinan kejahatan atau kekerasan." Berdasarkan definisi ini, proyek Indikator Tata Kelola Seluruh Dunia telah mengembangkan pengukuran agregat untuk aturan hukum di lebih dari 200 negara (Raz, 2017).

Pembukaan Konvensi Eropa untuk Perlindungan Hak Asasi Manusia dan Kebebasan Fundamental mengatakan "pemerintah negara-negara Eropa yang berpikiran sama dan memiliki warisan yang sama dari tradisi politik, cita-cita, kebebasan dan supremasi hukum" (Chesterman, 2008).

Di Perancis dan Jerman konsep aturan hukum (Etat de droit dan Rechtsstaat masing-masing) adalah analog dengan prinsip-prinsip supremasi konstitusi dan perlindungan hak-hak dasar dari otoritas publik (lihat hukum publik), khususnya legislatif. Perancis adalah salah satu pionir awal dari ide-ide aturan hukum. Interpretasi Jerman lebih "kaku" tetapi mirip dengan Perancis dan Inggris. Konstitusi Finlandia secara eksplisit mensyaratkan aturan hukum dengan menetapkan bahwa "pelaksanaan kekuasaan publik harus didasarkan pada Undang-Undang. Dalam semua aktivitas publik, hukum harus diawasi secara ketat." Di Britania Raya, aturan hukum adalah prinsip yang berlaku lama tentang cara negara diatur, berasal dari Magna Carta pada tahun 1215 dan Bill of Rights 1689. Pada abad ke-19, AV Dicey (1915 dan 2013), seorang sarjana konstitusi dan pengacara, menulis tentang pilar kembar konstitusi Inggris dalam karya klasiknya Pengantar Studi Hukum Konstitusi (1885); kedua pilar ini adalah aturan hukum dan kedaulatan parlementer . 
Semua pejabat pemerintah Amerika Serikat, termasuk Presiden, Hakim Mahkamah Agung, hakim dan legislator negara bagian, dan semua anggota Kongres, berjanji untuk menegakkan Konstitusi. Sumpah ini menegaskan bahwa supremasi hukum lebih unggul daripada aturan pemimpin manusia. Pada saat yang sama, pemerintah federal memiliki keleluasaan yang cukup besar. Cabang legislatif bebas untuk memutuskan undang-undang apa yang akan ditulisnya, selama tetap berada di dalam wewenangnya yang disebutkan dan menghormati hak-hak individu yang dilindungi secara konstitusional. Demikian juga, cabang yudisial yang memiliki tingkat kebijaksanaan peradilan, dan cabang eksekutif juga memiliki berbagai wewenang discretionary termasuk kebijaksanaan penuntutan .

Para sarjana terus memperdebatkan apakah Konstitusi AS mengadopsi interpretasi khusus dari "aturan hukum". Misalnya, John Harrison (1965)menegaskan bahwa kata "hukum" dalam Konstitusi secara sederhana didefinisikan sebagai kata yang mengikat secara hukum, bukannya "didefinisikan oleh kriteria formal atau substantif", dan oleh karena itu hakim tidak memiliki keleluasaan untuk memutuskan bahwa hukum gagal memenuhi kriteria tidak tertulis dan tidak jelas seperti itu. Profesor Hukum Frederick Mark Gedicks (1989: 99) tidak setuju, menulis bahwa Cicero, Agustinus, Thomas Aquinas, dan para perumus Konstitusi AS percaya bahwa hukum yang tidak adil bukanlah benarbenar hukum sama sekali.

Beberapa sarjana modern berpendapat bahwa aturan hukum telah erosi selama abad yang lalu oleh pandangan instrumental hukum yang dipromosikan oleh realis hukum seperti Oliver Wendell Holmes (1996) dan Roscoe Pound (1938). Misalnya, Brian Tamanaha menegaskan: "Aturan hukum adalah cita-cita yang berusia berabad-abad, tetapi gagasan bahwa hukum adalah sarana untuk mencapai tujuan menjadi mengakar dalam perjalanan abad kesembilan belas dan kedua puluh."

Yang lain berpendapat bahwa aturan hukum telah bertahan tetapi diubah pelaksanaan kebijaksanaannya oleh administrator. Untuk sebagian besar sejarah Amerika, gagasan dominan dari aturan hukum, dalam pengaturan ini, telah menjadi beberapa versi AV Dicey (2013) menegaskan: "tidak ada orang yang dapat dihukum atau dapat secara sah dibuat untuk menderita dalam tubuh atau barang 
kecuali untuk pelanggaran hukum yang didirikan dengan cara hukum biasa sebelum Pengadilan negeri biasa. " Artinya, individu harus dapat menantang perintah administratif dengan membawa gugatan di pengadilan yurisdiksi umum. Karena pembayaran komisi kompensasi pekerja, komisi utilitas publik, dan agensi lainnya meningkat, hal ini menjadi jelas bahwa membiarkan hakim memutuskan sendiri semua fakta dalam perselisihan (seperti tingkat cedera dalam kasus kompensasi pekerja) akan membebani pengadilan dan menghancurkan keuntungan dari spesialisasi yang mengarah pada pembentukan lembaga administratif di tempat pertama.

Bahkan Charles Evans Hughes (1973), seorang Hakim Agung Amerika Serikat, percaya "Kita harus memiliki administrasi, dan Kita harus memiliki administrasi oleh petugas administrasi." Pada 1941, sebuah kompromi muncul. Jika administrator mengadopsi prosedur yang kurang lebih mengikuti "cara hukum biasa" dari pengadilan, peninjauan lebih lanjut atas fakta oleh "Pengadilan Negeri biasa" tidak diperlukan. Artinya, jika Kita memiliki "hari di pengadilan", aturan hukum tidak memerlukan "hari di pengadilan" lebih lanjut. Dengan demikian, aturan hukum Dicey disusun kembali menjadi bentuk prosedural murni.

James Wilson (1787) mengatakan selama Konvensi Philadelphia pada 1787 bahwa, "Hukum mungkin tidak adil, mungkin tidak bijaksana, mungkin berbahaya, mungkin merusak. Namun tidak terlalu inkonstitusional untuk membenarkan Hakim menolak memberi mereka efek." George Mason setuju bahwa hakim "dapat menyatakan kekosongan hukum inkonstitusional. Tetapi berkenaan dengan setiap undang-undang, bagaimanapun tidak adil, menindas atau merusak, yang tidak muncul dengan jelas di bawah uraian ini, mereka harus berada di bawah kebutuhan sebagai hakim untuk memberikannya jalan kebebasan. Hakim Agung John Marshall (bergabung dengan Justice Joseph Story) mengambil posisi yang sama pada tahun 1827:" Ketika keberadaannya sebagai hukum ditolak, eksistensi itu tidak dapat dibuktikan dengan menunjukkan kualitas sebuah hukum seperti apa (Ackerman, 1991). 


\section{Basis Kultural bagi Nomokrasi}

Di Asia Tenggara, pemikiran politik dipengaruhi oleh Islam dan Hinduisme dan Budhisme serta agama-agama lokal yang keumdian menjadi local wisdom yang tampil dalam banyak ekspresi politik masyarakatnya. Budaya Asia Timur dipengaruhi oleh dua aliran pemikiran Konfusianisme, yang menganjurkan pemerintahan yang baik sebagai aturan oleh para pemimpin yang bijak dan berbudi luhur, dan Legalisme, yang menganjurkan kepatuhan yang ketat terhadap hukum. Pengaruh satu aliran pemikiran atas yang lain telah bervariasi selama berabad-abad. Satu penelitian menunjukkan bahwa di seluruh Asia Timur, hanya Korea Selatan, Singapura, Jepang, Taiwan, dan Hong Kong yang memiliki masyarakat yang berkomitmen kuat terhadap negara yang terikat hukum. Menurut Awzar Thi (2007), anggota Komisi Hak Asasi Manusia Asia, aturan hukum di Thailand, Kamboja, dan sebagian besar Asia lemah atau bahkan mungkin tidak ada.

Terlepas dari sejumlah negara bagian dan teritori, di seluruh benua ada jurang pemisah besar antara retorika aturan hukum dan kenyataan. Di Thailand, kepolisian adalah geng kejahatan terorganisir (Thi, 2008). Di Kamboja, hakim adalah proksi untuk partai politik yang berkuasa. Bahwa seorang hakim dapat menyimpan prasangka politik atau menerapkan hukum secara tidak merata adalah kekhawatiran terkecil bagi terdakwa kriminal biasa di Asia (Hewison, 2013). Yang lebih mungkin adalah: Akankah polisi mengarang bukti? Apakah jaksa akan muncul? Akankah hakim tertidur? Apakah saya akan diracuni di penjara? Apakah kasus seseorang akan selesai dalam satu dekade?

Di negara-negara seperti Cina dan Vietnam, peralihan ke ekonomi pasar telah menjadi faktor utama dalam bergerak menuju aturan hukum, karena aturan hukum penting bagi investor asing dan pembangunan ekonomi. Masih belum jelas apakah aturan hukum di negara-negara seperti Cina dan Vietnam akan terbatas pada masalah komersial atau akan tumpah ke area lain juga, dan jika demikian apakah spillover itu akan meningkatkan prospek untuk nilai-nilai terkait seperti demokrasi dan hak asasi manusia. Aturan hukum di Tiongkok telah banyak didiskusikan dan diperdebatkan oleh para sarjana hukum dan politisi di Tiongkok (Thayer, 2017). 
Di Thailand, sebuah kerajaan yang telah memiliki konstitusi sejak upaya awal untuk menggulingkan sistem monarki absolut (Thi, 2008). Pada tahun 1932, supremasi hukum lebih merupakan prinsip daripada praktik yang sebenarnya. Prasangka kuno dan bias politik telah hadir di tiga cabang pemerintahan dengan masing-masing pendirian mereka, dan keadilan telah diproses secara formal sesuai dengan hukum tetapi sebenarnya lebih erat sejalan dengan prinsip-prinsip kerajaan yang masih dianjurkan pada abad 21 (Ambuel, 2001). Pada bulan November 2013, Thailand dihadapkan masih ancaman lebih lanjut terhadap aturan hukum ketika cabang eksekutif menolak keputusan pengadilan tertinggi tentang bagaimana memilih senator (Klein, 2003).

Di India, teks konstitusional terpanjang dalam sejarah dunia telah mengatur negara itu sejak tahun 1950. Meskipun Konstitusi India mungkin dimaksudkan untuk memberikan rincian yang akan membatasi kesempatan untuk diskresi peradilan, semakin banyak teks yang ada dalam konstitusi Peluang yang lebih besar dan peradilan mungkin harus melakukan peninjauan hukum kembali. Menurut wartawan India, Harish Khare (2015), mengatakan bahwa "Aturan hukum atau lebih tepatnya Konstitusi berada dalam bahaya apabila digantikan oleh aturan hakim."

Jepang memiliki berabad-abad tradisi sebelum Perang Dunia II, di mana ada undang-undang, tetapi mereka tidak memberikan prinsip pengorganisasian sentral untuk masyarakat, dan mereka tidak membatasi kekuasaan pemerintah (Boadi, 2001). Ketika abad 21 dimulai, persentase orang-orang yang menjadi pengacara dan hakim di Jepang tetap sangat rendah dibandingkan dengan Eropa Barat dan Amerika Serikat, dan undang-undang di Jepang cenderung singkat dan umum, meninggalkan banyak kebijaksanaan di tangan birokrat.

Statuta Dewan Eropa mencirikan aturan hukum sebagai salah satu prinsip inti yang mendasari terbentuknya organisasi. Paragraf 3 dari Pembukaan Statuta Dewan Eropa menyatakan: "Meneguhkan kembali kesetiaan mereka pada nilainilai spiritual dan moral yang merupakan warisan umum dari masyarakat mereka dan sumber sejati kebebasan individu, kebebasan politik dan supremasi hukum, prinsip-prinsip yang membentuk dasar dari semua demokrasi sejati. " Statuta 
menetapkan kepatuhan dengan aturan prinsip hukum sebagai syarat bagi negaranegara Eropa untuk menjadi anggota penuh organisasi

Pada tahun 1959, sebuah peristiwa terjadi di New Delhi dan berbicara sebagai Komisi Ahli Hukum Internasional, membuat deklarasi mengenai prinsip dasar supremasi hukum. Acara ini terdiri dari lebih dari 185 hakim, pengacara, dan profesor hukum dari 53 negara. Ini kemudian dikenal sebagai Deklarasi Delhi (Yardley, 1961: 673). Selama deklarasi mereka menyatakan apa yang disiratkan oleh aturan hukum. Mereka termasuk hak dan kebebasan tertentu, peradilan independen dan sosial, ekonomi dan budaya yang kondusif bagi martabat manusia. Satu aspek yang tidak termasuk dalam Deklarasi Delhi, adalah untuk aturan hukum yang mensyaratkan kekuasaan legislatif untuk ditinjau kembali. Sekretaris Jenderal Perserikatan Bangsa-Bangsa (Tolbert, 2006) mendefinisikan aturan hukum sebagai:

sebuah prinsip pemerintahan di mana semua orang, lembaga dan badan, publik dan swasta, termasuk Negara itu sendiri, bertanggung jawab terhadap hukum yang diumumkan secara terbuka, ditegakkan dan diadili secara independen, dan yang konsisten dengan norma dan standar hak asasi manusia internasional. Hal ini membutuhkan, juga, langkah-langkah untuk memastikan kepatuhan terhadap prinsip-prinsip supremasi hukum, kesetaraan di depan hukum, akuntabilitas terhadap hukum, keadilan dalam penerapan hukum, pemisahan kekuasaan, partisipasi dalam pengambilan keputusan, kepastian hukum, penghindaran kesewenang-wenangan dan transparansi prosedural dan hukum.

Majelis Umum telah mempertimbangkan aturan hukum sebagai item agenda sejak 1992, dengan minat baru sejak 2006 dan telah mengadopsi resolusi pada tiga sesi terakhirnya (Walker, 1988). Dewan Keamanan telah mengadakan sejumlah perdebatan tematis mengenai aturan hukum, dan resolusi yang diadopsi yang menekankan pentingnya isu-isu ini dalam konteks perempuan, perdamaian dan keamanan, anak-anak dalam konflik bersenjata, dan perlindungan warga sipil dalam konflik bersenjata. Komisi Peacebuilding juga secara teratur membahas masalah aturan hukum sehubungan dengan negara-negara dalam agendanya. Deklarasi Wina dan Program Aksi juga mensyaratkan aturan hukum dimasukkan dalam pendidikan hak asasi manusia. 
Dewan Asosiasi Pengacara Internasional mengeluarkan resolusi pada tahun 2009 yang mengesahkan definisi yang substantif atau "tebal" dari aturan hukum (Stein, 2009):

Peradilan yang independen dan tidak memihak, praduga tak bersalah, hak atas pengadilan yang adil dan terbuka tanpa penundaan yang lama. pendekatan yang rasional dan proporsional terhadap hukum, profesi hukum yang kuat dan independen, perlindungan ketat komunikasi rahasia antara pengacara dan klien, kesetaraan semua sebelum hukum, ini semua adalah prinsip dasar dari Rule of Law.

Dengan demikian, penangkapan sewenang-wenang, uji coba rahasia, penahanan tak terbatas tanpa pengadilan, perlakuan atau hukuman yang kejam atau merendahkan, intimidasi atau korupsi dalam proses pemilihan, semuanya tidak dapat diterima. Aturan Hukum adalah dasar dari masyarakat yang beradab. Ini menetapkan proses transparan yang dapat diakses dan setara dengan semua. Ini memastikan kepatuhan pada prinsip-prinsip yang membebaskan dan melindungi. IBA menyerukan kepada semua negara untuk menghormati prinsipprinsip dasar ini. Ini juga menyerukan kepada anggotanya untuk bersuara mendukung Aturan Hukum di dalam komunitas mereka masing-masing (Dieng, 1997).

Sebagaimana digunakan oleh Proyek Keadilan Dunia, sebuah organisasi nirlaba yang berkomitmen untuk memajukan supremasi hukum di seluruh dunia, aturan hukum mengacu pada sistem berbasis aturan di mana empat prinsip universal berikut ditegakkan:

1. Pemerintah dan pejabat dan agennya bertanggung jawab di bawah hukum.

2. Undang-undangnya jelas, dipublikasikan, stabil, adil, dan melindungi hakhak dasar, termasuk keamanan orang dan properti.

3. Proses di mana undang-undang diberlakukan, diatur, dan ditegakkan dapat diakses, adil, dan efisien,

4. Akses terhadap keadilan disediakan oleh adjudicator yang kompeten, independen, dan etis, pengacara atau perwakilan, dan petugas peradilan 
yang memiliki jumlah yang cukup, memiliki sumber daya yang memadai, dan mencerminkan susunan komunitas yang mereka layani. ${ }^{4}$

Organisasi Pembangunan Hukum Internasional (IDLO, International Development of Law Organization) adalah organisasi antar pemerintah dengan fokus bersama pada promosi aturan hukum dan pembangunan. Ia bekerja untuk memberdayakan masyarakat dan komunitas untuk mengklaim hak mereka, dan memberi pemerintah pengetahuan untuk merealisasikannya. Mendukung negaranegara berkembang dan negara-negara berpenghasilan menengah untuk memperkuat kapasitas hukum dan aturan hukum mereka untuk pembangunan berkelanjutan dan peluang ekonomi. Ini adalah satu-satunya organisasi antar pemerintah dengan mandat eksklusif untuk mempromosikan supremasi hukum dan memiliki pengalaman bekerja di lebih dari 170 negara di seluruh dunia (IDLO, 2015).

Organisasi Hukum Pembangunan Internasional memiliki definisi holistik dari aturan hukum: Lebih dari sekadar masalah proses hukum, supremasi hukum adalah pendukung keadilan dan pembangunan. Ketiga gagasan itu saling bergantung; ketika disadari, mereka saling memperkuat. Untuk IDLO, sebanyak masalah hukum dan prosedur, aturan hukum adalah budaya dan praktik seharihari. Ini tidak dapat dipisahkan dari kesetaraan, dari akses ke keadilan dan pendidikan, dari akses ke kesehatan dan perlindungan yang paling rentan. Sangat penting untuk kelangsungan hidup masyarakat dan negara, dan untuk lingkungan yang mendukung mereka. IDLO berkantor pusat di Roma dan memiliki kantor cabang di Den Haag dan memiliki Status Pengamat Permanen di Majelis Umum PBB di New York City (Heupel, 2012).

Jaringan Internasional untuk Mempromosikan Aturan Hukum (The International Network to Promote the Rule of Law, INPROL) adalah jaringan lebih dari 3.000 praktisi hukum dari 120 negara dan 300 organisasi yang bekerja di

4 Proyek Keadilan Dunia (World Justice Project) telah mengembangkan Indeks untuk mengukur sejauh mana negara-negara mematuhi aturan hukum dalam praktek keseharian di negara negara dunia ketiga. The WJP Rule of Law Index terdiri dari 9 faktor dan 52 sub-faktor, dan mencakup berbagai dimensi aturan hukum seperti apakah pejabat pemerintah bertanggungjawab di bawah hukum, dan apakah lembaga hukum melindungi hak-hak dasar dan membiarkan orang biasa mengakses ke pengadilan (Agrast, Botero, 2010). 
bidang aturan hukum di negara-negara pasca-konflik dan berkembang dari perspektif kebijakan, praktik dan penelitian. INPROL berbasis di US Institute of Peace (USIP) dalam kemitraan dengan Departemen Biro Luar Negeri Narkotika Internasional dan Penegakan Hukum, Organisasi untuk Keamanan dan Kerjasama di Eropa (OSCE) Strategic Police Matters Unit, Pusat Keunggulan untuk Polisi, dan William and Marry School of Law di Amerika Serikat (Dworkin, 1951).

Organisasi afiliasinya termasuk Kantor PBB untuk Narkoba dan Kejahatan, Akademi Folke Bernadotte, Asosiasi Bar Internasional, Asosiasi Kepala Polisi Internasional, Asosiasi Polisi Wanita Internasional, Lembaga Pemasyarakatan dan Penjara Internasional, Asosiasi Internasional untuk Administrasi Pengadilan, Penasehat Sektor Keamanan Internasional Tim di Pusat Jenewa untuk Pengendalian Demokratis Angkatan Bersenjata, Asosiasi Ahli Forensik Wanita Seluruh Dunia (WAWFE), dan Lembaga Internasional untuk Hukum dan Hak Asasi Manusia (Agrast, 2013).

INPROL menyediakan forum online untuk pertukaran informasi tentang praktik terbaik. Para anggota dapat mengajukan pertanyaan, dan mengharapkan tanggapan dari rekan praktisi hukum mereka di seluruh dunia tentang pengalaman mereka dalam mengatasi masalah aturan negara hukum (O'Connor, 2015).

\section{Penutup}

Indonesia perlu membuang sistem demokrasi dan menerapkan sistem nomokrasi murni. Artinya, partai politik tidak dipakai sama sekali dan menggantinya dengan sistem pemilihan multistage representative election system. Perlindungan kelompok-kelompok kultural kecil perlu dilakukan dengan menempatkan mereka yang minoritas (suku dan agama) bisa duduk di parlemen, tanpa mengikuti kaedah parliamentary threshold. Kepastian dan jaminan terhadap representasi golongan atau kelompok minoritas ini sangat penting bagi Indonesia dan juga bagi semua negara yang perlu mewujudkan cita-cita persamaan hak dan kewajiban bagi semua warga negara.

Jaminan nomokratis terhadap dunia usaha juga sangat penting, sama pentingnya dengan jaminan terhadap kelompok-kelompok etnik dan agama 
minoritas. Salah satu aspek penting dari inisiatif rule-of-law adalah studi dan analisis pengaruh rule of law pada pembangunan ekonomi. Gerakan rule-of-law tidak dapat sepenuhnya berhasil di negara-negara transisi dan berkembang tanpa jawaban atas pertanyaan: apakah aturan hukum penting untuk pembangunan ekonomi atau tidak? Ekonomi konstitusi adalah studi tentang kompatibilitas ekonomi dan keuangan keputusan dalam kerangka hukum konstitusional yang ada, dan kerangka kerja tersebut mencakup pengeluaran pemerintah pada lembaga peradilan di banyak negara transisional dan berkembang yang sepenuhnya dikendalikan oleh eksekutif. Dan berguna untuk membedakan antara dua metode korupsi peradilan: korupsi oleh cabang eksekutif, berbeda dengan korupsi oleh aktor swasta.

Standar ekonomi konstitusional dapat digunakan selama proses anggaran tahunan, dan jika perencanaan anggaran itu transparan maka aturan hukum dapat menguntungkan. Ketersediaan sistem pengadilan yang efektif, yang akan digunakan oleh masyarakat sipil dalam situasi pembelanjaan pemerintah yang tidak adil dan pelarangan eksekutif dari pengalokasian sebelumnya yang merupakan elemen kunci untuk keberhasilan upaya hukum dalam melaksanakan prinsip rule of law secara komprehensif. Semestinya Indonesia menerapkan sistem nomokrasi Islam sedari awal negara ini berdiri untuk menjaga sistem pemerintahan yang adil dan bertanggungjawab bagi seluruh rakyat. ${ }^{5}$

Aturan Hukum sangat penting sebagai pengaruh pada perkembangan ekonomi di negara-negara berkembang dan transisi. Sampai saat ini, istilah "aturan hukum" telah digunakan terutama di negara-negara yang berbahasa Inggris, dan belum sepenuhnya diklarifikasi bahkan berkaitan dengan demokrasi yang mapan. Misalnya, Swedia, Denmark, Prancis, Jerman, atau Jepang. Bahasa umum antara pengacara hukum umum dan negara hukum perdata serta antara komunitas hukum negara maju dan berkembang sangat penting untuk penelitian hubungan antara aturan hukum dan ekonomi riil.

5 "NOMOKRASI ISLAM - Blogger." https://nahayeu.blogspot.com/2016/02/nomokrasiislam.html. 
"Aturan hukum" terutama berkonotasi "perlindungan hak milik" bagi seluruh rakyat khususnya pelaku bisnis. Ekonom F. A. Hayek (1989) menganalisis bagaimana aturan hukum dapat bermanfaat bagi pasar bebas. Hayek mengusulkan bahwa di bawah aturan hukum, individu akan mampu membuat investasi yang bijaksana dan rencana masa depan dengan keyakinan dalam pengembalian investasi yang sukses ketika ia menyatakan: "di bawah Rule of Law pemerintah dicegah dari upaya individu yang melemahkan oleh aturan permainan ad hoc, individu bebas untuk mengejar tujuan dan keinginan pribadinya, yakin bahwa kekuatan pemerintah tidak akan digunakan dengan sengaja untuk menggagalkan usahanya" (Hayek, 2012: 97).

Banyak penelitian telah menunjukkan bahwa aturan hukum yang lemah (misalnya, penegakan peraturan yang tidak mengikat) menghambat investasi. Para ekonom telah menemukan bahwa peningkatan penegakan peraturan diskresioner menyebabkan perusahaan AS meninggalkan investasi internasional. Upaya untuk menerapkan omnibus law di Indonesia hanya akan mencederai negara hukum yang sudah berdiri sejak 1945 dengan semangat egalitarianisme dan emansipasi syariat yang kuat.

Perjanjian tentang Perlindungan Institusi dan Monumen Bersejarah atau Pakta Roerich adalah perjanjian antar Amerika (Schipper, 2013). Ide terpenting dari Pakta Roerich adalah pengakuan hukum bahwa pembelaan benda-benda budaya lebih penting daripada penggunaan atau penghancuran budaya itu untuk tujuan militer, dan perlindungan budaya selalu didahulukan daripada kebutuhan militer. Pakta Roerich ditandatangani pada 15 April 1935 oleh perwakilan 21 negara bagian Amerika di Kantor Oval Gedung Putih di Washington, DC (Roerich Pact, 1947). Ini adalah perjanjian internasional pertama yang ditandatangani di Oval Office. Konvensi Den Haag untuk Perlindungan Properti Budaya dalam Peristiwa Konflik Bersenjata adalah perjanjian internasional pertama yang berfokus pada perlindungan properti budaya dalam konflik bersenjata. Itu ditandatangani di Den Haag, Belanda pada 14 Mei 1954 dan mulai berlaku pada 7 Agustus 1956, dan pada Juni 2017, telah diratifikasi oleh 128 negara (Hilda, 2013).

Aturan hukum dapat terhambat ketika ada pemutusan hubungan antara konsensus hukum dan aspirasi populer. Contohnya adalah kekayaan intelektual. Di 
bawah naungan Organisasi Kekayaan Intelektual Dunia, undang-undang hak cipta yang sangat kuat telah diterapkan di sebagian besar dunia, tetapi karena sikap sebagian besar penduduk tidak sesuai dengan undang-undang ini, pemberontakan terhadap hak kepemilikan telah diwujudkan dalam pembajakan yang merajalela, termasuk peningkatan dalam berbagi file antar-rekan. Demikian pula, di Rusia, penggelapan pajak adalah hal yang biasa dan orang yang mengaku tidak membayar pajak tidak dinilai atau dikritik oleh rekan-rekan dan teman-temannya, karena sistem pajak dipandang tidak masuk akal. Suap juga memiliki implikasi normatif yang berbeda antar budaya. Aturan Hukum telah dikritik oleh beberapa sarjana, penulis, filsuf dan aktivis karena tidak realistis, munafik atau berbahaya.

Peter Gelderloos (2007) berpendapat bahwa mencoba menciptakan kelas khusus otoritas peradilan yang terpisah dari komunitas pasti akan mengarah pada korupsi. Dia menunjukkan bahwa pelanggaran terkait narkoba tanpa kekerasan menerima lebih banyak perhatian polisi dan media daripada cedera atau pencemaran di tempat kerja, yang membunuh lebih banyak orang setiap tahun. Dia berpendapat bahwa keadilan restoratif adalah alternatif yang jauh lebih efektif dan manusiawi untuk penjara, pengadilan dan polisi. Keadilan restoratif adalah sistem hukum yang sangat dekat dan sangat sesuai dengan sistem nomokrasi Islam.

Untuk membahas konsep dan teori besar tentang nomokrasi ini, penelitian ini merujuk pada konsep-konsep dan teori Ibnu Khaldun (1977). Di sini akan dibahas sedikit tentang perkembangan sejarah Ibnu Khaldun yang nama aslinya adalah Abū Zayd 'Abd ar-Raḥmān ibn Muḥammad ibn Khaldūn al-Haḍramī; lahir 27 Mei 1332 - 17 Maret 1406). Ibnu Khaldun adalah seorang historiografer dan sejarawan Arab Tunisia yang dianggap oleh beberapa orang Barat sebagai ayah sejati historiografi dan sosiolog, mengatakan bahwa: siyasah diniyah sebagai sistem politik terbaik. "Ibn Khaldun telah diklaim sebagai pelopor dari sejumlah besar pemikir Eropa, kebanyakan sosiolog, sejarawan, dan filsuf". Menurut Boulakia (1971), Ibnu Khaldun adalah "Bapak pendiri Sosiologi Timur" yang bukan hanya milik umat islam, namun juga milik dunia. Skema besar untuk menemukan ilmu baru ini masyarakat membuatnya menjadi pelopor dari banyak pembangun sistem abad kedelapan belas dan kesembilan belas seperti Vico, Comte dan Marx. Sebagai salah satu pendiri awal ilmu sosial seperti sosiologi dan antropologi. 
Ibnu Khaldun dianggap oleh beberapa orang sebagai Bapak Ekonomi Modern, atau seorang pelopor besar dalam ilmu politik, sosiologi dan antropologi. Dunia Barat mengakui Khaldun sebagai bapak sosiologi tetapi ragu-ragu untuk mengakui Ibnu Khaldun sebagai seorang ekonom besar yang meletakkan fondasinya. Ibnu Khaldun adalah yang pertama menganalisis fungsi ekonomi, pentingnya teknologi, spesialisasi dan perdagangan luar negeri dalam surplus ekonomi dan peran pemerintah terhadap kebijakan stabilisasi untuk meningkatkan output dan pekerjaan. Selain itu, ia berurusan dengan masalah perpajakan optimal, layanan pemerintah minimum, insentif, kerangka kerja institusional, hukum dan ketertiban, harapan, produksi, dan teori nilai. Hasil ilmu pengetahuan Ibnu Khaldun ini mustilah diejawantahkan ke dalam sistem negara dan pemerintahan, khususnya di Indonesia.*** 


\section{Daftar Pustaka}

Ackerman, Bruce. "The Common Law Constitution of John Marshall Harlan." NYL Sch. L. Rev. 36 (1991): 5.

Agrast, Mark David, et al. The world justice project rule of law index: 2012-2013. Univerza v Mariboru, Pravna fakulteta, 2013.

Agrast, Mark David, Juan Carlos Botero, and Alejandro Ponce. The world justice project: rule of law index 2010. World Justice Project, 2010.

Alfasi, Nurit, and Juval Portugali. "Planning rules for a self-planned city." Planning theory 6.2 (2007): 164-182.

Ambuel, David. "New karma: buddhist democracy and the rule of law in thailand." American Asian Review 19.4 (2001): 131.

Ibrahim, Armia. "Peraturan Perundang-Undangan Tentang Pelaksanaan Syariat Islam di Aceh." (2009).

Batty, Michael, and Paul M. Torrens. "Modelling and prediction in a complex world." Futures 37.7 (2005): 745-766.

bin Khaldun, Al-Allamah AbdurrahmanMuhammad. Mukaddimah Ibnu Khaldun. Jakarta Pustaka Al Kautsar, 2011.

Bingham, Tom. The rule of law. Penguin UK, 2011.

Boulakia, Jean David C. "Ibn Khaldun: a fourteenth-century economist." Journal of Political Economy 79.5 (1971): 1105-1118.

Boyer, Allen Dillard. "Understanding, Authority, and Will: Sir Edward Coke and the Elizabethan Origins of Judicial Review." BCL Rev. 39 (1997): 43.

Carothers, Thomas. "The rule of law revival." Foreign Aff. 77 (1998): 95.

Chesterman, Simon. "An international rule of law?." The American Journal of Comparative Law 56.2 (2008): 331-362.

Cheung, Chor Y. "Hayek on Nomocracy and Teleocracy: A Critical Assessment." Cosmos+ Taxis 1.2 (2014): 24-33.

Cicero, Marcus Tullius. Cicero: On moral ends. Cambridge University Press, 2001.

Coffey, John. Politics, religion and the British revolutions: The mind of Samuel Rutherford. Cambridge University Press, 1997.

Dicey, Albert Venn. Introduction to the study of the law of the constitution/by AV Dicey. London: Macmillan, 1915, 1915.

Dicey, Albert Venn. The law of the constitution. Vol. 1. Oxford University Press, 2013.

Dieng, Adama. "Role of judges and lawyers in defending the rule of law." Fordham Int'l LJ 21 (1997): 550.

Dworkin, Ira Bernard. "America's First Law School: The College of William and Mary." ABAJ 37 (1951): 348.

Fallon Jr, Richard H. "" The rule of law" as a concept in constitutional discourse." Columbia Law Review (1997): 1-56.

Fornaciari, Gino, et al. "" Royal" pediculosis in Renaissance Italy: lice in the mummy of the King of Naples Ferdinand II of Aragon (1467-1496)." Memórias do Instituto Oswaldo Cruz 104.4 (2009): 671-672.

Gedicks, Frederick Mark. "Toward a constitutional jurisprudence of religious group rights." Wis. L. Rev. (1989): 99. 
Gelderloos, Peter. How nonviolence protects the state. Cambridge: South End Press, 2007.

Gyimah-Boadi, Emmanuel. "A peaceful turnover in Ghana." Journal of Democracy 12.2 (2001): 103-117.

Harrington, James, John Toland, and John Hall. The Oceana of James Harrington, Esq: And His Other Works: with an Account of His Life Prefix'd. R. Reilly, 1737.

Harrison, John, and Peter Laslett. The Library of John Locke: By John Harrison and Peter Laslett. Oxford University Press, 1965.

Hayek, Friedrich August. Hayek on Hayek: An autobiographical dialogue. University of Chicago Press, 2012.

Hayek, Friedrich August. The collected works of FA Hayek. Vol. 3. University of Chicago Press, 1989.

Heupel, Monika. "Rule of Law Promotion and Security Sector Reform: Common Principles, Common Challenges." Hague Journal on the Rule of Law 4.1 (2012): 158-175.

Hewison, Kevin. "Weber, Marx and contemporary Thailand." TRaNS: TransRegional and-National Studies of Southeast Asia 1.2 (2013): 177-198.

Hikmawati, Puteri. "Relevansi Pelaksanaan Syariat Islam di Provinsi Nanggroe Aceh Darussalam dengan Hukum Pidana Nasional." Jurnal Kajian 14.2 (2008).

Hilda. "Status and Binding Power of the Denhaag Convention 1954." Jurnal Cita Hukum-Indonesian Law Journal 1.1 (2013): 109-122.

Holmes, Oliver Wendell. The Essential Holmes: Selections from the Letters, Speeches, Judicial Opinions, and Other Writings of Oliver Wendell Holmes, Jr. University of Chicago Press, 1996.

https://www.researchgate.net/publication/258179130_Rethinking_the_theory_an d_practice_of_land-use_regulation_Towards_nomocracy [diakses 10 Sep 2018].

Hughes, Charles Evans. The autobiographical notes of Charles Evans Hughes/edited by David J. Danelski and Joseph S. Tulchin. Cambridge, Mass.: Harvard University Press, 1973, 1973.

Husaini, S. Waqar Ahmed, Anas Mahyudin, and Ammar Haryono. Sistem Pembinaan Masyarakat Islam. Bandung: Penerbit Pustaka, 1980.

International Law Association. "New Delhi Declaration of Principles of International Law Relating to Sustainable Development." Netherlands International Law Review 49.2 (2002).

Johnson, Samuel. A Dictionary of the English Language: In which the Words are Deduced from Their Originals; and Illustrated in Their Different Significations by Examples from the Best Writers. Henry G. Bohn, 1850.

Kartosoewirjo, Sekarmadji Maridjan. Haloean Politik Islam. Dewan Penerangan Masjoemi Daerah Priangan, 1946.

Kasper, Wolfgang. "A Generation of Reform." MPS 10 (2010): 15.

Kerr, Malcolm H. "Islamic reform: The political and legal theories of Muhammad'Abduh and Rashid Rida." (1966).

Khaldun, Allama Abdur Rahman Ibn. Muqaddamah ibn Khaldun. Nafees Academy, 1977.

Khare, Harish. How Modi Won It: notes from the 2014 election. Hachette India, 2015. 
Klein, James R. "The Battle for the Rule of Law in Thailand: The constitutional court of Thailand." The Constitutional Court of Thailand. The Provisions and the Working of the Court (2003): 34-90.

Levinson, Bernard M. Deuteronomy and the hermeneutics of legal innovation. Oxford University Press, USA, 2002.

Locke, John. The Works of John Locke. Vol. 6. T. Longman, B. Law, 1794.

Montesquieu, Charles. The Spirit of the Laws, Paris (1949).

Moroni, Stefano. "Planning, liberty and the rule of law." Planning Theory 6.2 (2007): 146-163.

Moroni, Stefano. "Rethinking the theory and practice of land-use regulation: Towards nomocracy." Planning Theory 9.2 (2010): 137-155.

O'Connor, Vivienne. "Defining the rule of law and related concepts." Available at SSRN 2665650 (2015).

Ottenberg, Louis. "Magna Charta Documents: The Story Behind the Great Charter." American Bar Association Journal (1957): 495-572.

Peerenboom, Randall. China's long march toward rule of law. Cambridge University Press, 2002.

Peraturan-Perundang-Undangan-Tentang-Pelaksanaan-Syariat-Islam-DiAceh.Html.

Peters, Francis E., ed. Aristoteles Arabus: The oriental translations and commentaries of the Aristotelian Corpus. Vol. 2. Brill Archive, 1968.

Portugali, Juval, and Nurit Alfasi. "An approach to planning discourse analysis." Urban Studies 45.2 (2008): 251-272.

Portugali, Juval. "Complexity theory as a link between space and place." Environment and Planning A 38.4 (2006): 647-664.

Pound, Roscoe. The formative era of American law, by Roscoe Pound. Boston: Little, Brown and Company, 1938, 1938.

Radin, Margaret Jane. "Reconsidering the rule of law." BUL Rev. 69 (1989): 781.

Raz, Joseph. "The rule of law and its virtue." The rule of law and the separation of powers. Routledge, 2017. 77-94.

Roerich Pact, and Banner of Peace Committee. The Roerich Pact and the Banner of Peace. Roerich Pact and Banner of Peace Committee, 1947.

Scalia, Antonin. "The rule of law as a law of rules." U. Chi. l. reV. 56 (1989): 1175.

Schipper, Friedrich T., and Erich Frank. "A concise legal history of the protection of cultural property in the event of armed conflict and a comparative analysis of the 1935 Roerich Pact and the 1954 Hague Convention in the context of the law of war." Archaeologies 9.1 (2013): 13-28.

SDGs, I. D. L. O. "the rule of law: from the "what" to the "how"." Rome: International Development Law Organization (2015).

Slaev, Aleksandar D. "Property rights and methods of nomocratic planning." Planning Theory 15.3 (2016): 274-293.

Slaev, Aleksandar D. "The theory of nomocracy as a useful method of analysis and managing private, common, as well as mixed real-world property rights." Planning Theory 17.2 (2018): 301-304.

Slaev, Aleksandar D. "The theory of nomocracy as a useful method of analysis and managing private, common, as well as mixed real-world property rights." Planning Theory 17.2 (2018): 301-304. 
Stein, Robert. "Rule of law: what does it mean." Minn. J. Int'l L. 18 (2009): 293.

Syariat Islam Di Aceh, Http://Www.Ms-Aceh.Go.Id/Informasi-Umum/Artikel/120(diakses pada tanggal 11 juni 2014).

Tamanaha, Brian Z. On the rule of law: History, politics, theory. Cambridge University Press, 2004.

Thayer, Carlyle A., and David G. Marr. Vietnam and the Rule of Law. Canberra, ACT: Dept. of Political and Social Change, Research School of Pacific and Asian Studies, The Australian National University., 2017.

Thi, Awzar. "Asia needs a new rule-of-law debate." (2008).

Thi, Awzar. "The draft 2007 Constitution of Thailand: a generals' Charter in judges' clothing." Article 26 (2007): 42-52.

Tolbert, David, and Andrew Solomon. "United Nations reform and supporting the rule of law in post-conflict societies." Harv. Hum Rts. J. 19 (2006): 29.

Walker, Geoffrey de Q. The Rule of Law: foundation of constitutional democracy. Vol. 42. Melbourne: Melbourne University Press, 1988.

Webster, Christopher J., and Lawrence Wai-Chung Lai. Property rights, planning and markets: managing spontaneous cities. Edward Elgar Publishing, 2003.

Wilson, James. "Pennsylvania ratifying convention." Doc. Hist 2 (1787).

Witte, John. "One public religion, many private religions: John Adams and the 1780 Massachusetts Constitution." Emory Public Law Research Paper 05-22 (2004).

Yardley, D. C. M. "The Rule of Law in a Free Society: A Report on the International Congress of Jurists, New Delhi, India, January 5-10, 1959." (1961): 673-673. 